virtual work, and techniques for the use of scale models in structural analysis. He has been a member of the Steel Structures Committee of the British Welding Research Association and is a consultant to the Directorate of Extramural Research of the National Coal Board. He is the author of Model Analysis of Structures, Energy Principles in Applied Statics and Analysis of Statically. indeterminate Frameworks.

\section{Science in Parliament:}

The Overseas Information Services

THe debate on the Overseas Information Services in the House of Lords on March 26 was notable for the constructive and authoritative speeches from Viscount Massereene, Lord Taylor, Lord Bridges, Lord Eceles and the Earl of Lucas. Viscount Massereene said that the net expenditure of the Overseas Department of the Central Office of Information was about $£ 3$ million and nearly five million copies of British Government-produced magazines were distributed in seventeen languages. Lord Taylor, stressing the importance of accuracy and of personal contact, briefly mentioned the importanee of work for students and also the need for independent assessment of the value of information services. Lord Bridges dealt more especially with the work of the British Council, which he thought had the right set-up and gave the nation very good value for its expenditure, which had risen in the past six or seven years from about $£ 3$ million to $£ 9$ million a year and was now proceeding in 75 countries. He thought more could be done for English language teaching and in assisting other countries to build up their own public library services. Lord Eccles also urged more generous support for the teaching of English but suggested that it would be worth while inquiring further into the relative allocation of resources as between one type of overseas aid and another. The Earl of Lucas also referred to the need to do more for students in Britain, and the Duke of Devonshire, who replied on the debate for the Government, said that it was planned to provide over ten years some $£ 3$ million to provide 5,000 new student places in hostels, elubs, etc. This would include places for some 10-15 per cent of British students so as to avoid segregation and nearly 2,000 beds had already been provided.

Viscount Massereene, pointing out that the current expenditure on the Overseas Information Services, including broadeasting and television, was about $£ 23.5$ million, urged the Government to set up a fund of $£ 10$ million to enable Britain to equip the emergent nations with television stations, the cost of such stations averaging about $£ 1$ million. The Duke of Devonshire said that the Government planned to spend during the next four years $£ 4.5$ million on building four relay stations to extend the areas where the B.B.C. programmes may be heard and to strengthen the signal in existing fields. He also referred to the striking increase in television and in the demand for television material while the demand for reading material under the cheap-book scheme and for information about Britain was continually outstripping supply. The research work of the Centre for Educational Television set up last year had largely been completed and the centre was now trying out package programmes. Speaking for the Government earlier in the debate the Earl of Dundee said that the inquiry undertaken by the Secretary for Technical Co-operation, Mr. D. Vosper, had concluded that, apart from some minor economies, a substantial increase in expenditure on the Overseas Information Services was justified, and the Government has now agreed to increase Britain's total expenditure from $£ 20.8$ million in the current year to $£ 25.8$ million in 1963-64. Of this increase, about $£ 1$ million would be for entirely new services and the British Council's work in teaching the English language would be strengthened. Considerable funds were being provided for new techniques, such as television and language laboratories.
The British Museum Bill

Is the debate in the House of Lords on April 9, when the British Museum Bill received its second reading, the Earl of Cranbrook strongly pressed the need for more funds for the British Museum (Natural History) if it was to fulfil its function of research. Claiming that this was the greatest research institution of its kind in the world, he pointed out that its needs had been deliberately neglected by successive Governments for a generation and its allocation for the acquisition of books for the library and material for the collections, including the necessary travel abroad by scientists in 1961 , was still only the $£ 8,000$ allocated in 1931. He thought too that for such a research institution the composition of the Trustees should approximate to that of a research council and that at least fifty per cent of the members should be actively engaged in research, including a proportion of younger men. Lord Shackleton also stressed the importance of research and pressed for more information about the National Reference Library for Science and Invention, but he strongly criticized the present limited opening hours of the British Museum. $\mathrm{He}_{\theta}$ thought it intolerable that the Museum closed at 5 p.m. and that the Reading Room was open for only two evenings a week, nor did he think the Government appreciated the importance of the new Reference Library for Science and Invention. Beyond admitting the substance of these criticisms the Earl of Dundee, who replied on the debate, gave no indication of immediate Government action to improve the situation.

In the debates on the British Museum Bill in the House of Commons some concern was expressed at the separation of the British Museum, Bloomsbury, and the British Museum (Natural History), but the main criticism was in favour of separating, and moving the Departments of Antiquities rather than the Library itself. The eriticism in general was constructive and was aimed at improving the use made of the Museum and its Library, by removing administrative practices no longer appropriate, and in concluding the 'Third Reading' debate on March 27, the Chief Secretary to the Treasury, Mr. J. Boyd Carpenter, fully recognized this. $H_{\theta}$ thought that the Library project was the greatest contribution this generation could make to the British Museum, and he would be deeply disappointed if there were any check or delay in its exeeution. The capital cost of the new Library building would be about $£ 10$ million and the National Reference Library for Science and Invention on the South Bank would cost more than $£ 1$ million. The British Museum Vote had risen from $£ 350,000$ in $1952-53$ to $£ 1,122,000$ in the current year.

\section{Scientists in the Civil Service}

IN a written answer in the House of Commons on April 9, the Financial Secretary to the Treasury, Mr. A. Barber, gave the number of entrants to the Scientific Officer Class of the Civil Service in 1950 as 194, of which 82 had first-class honours degrees; for 1962 the corresponding figures were 204 and 50. On April 10, the Civil Lord of the Admiralty, Mr. C. I. Orr-Ewing said that more than 7,000 people were employed in the Admiralty's research and development establishments and annual expenditure totalled £26 million.

\section{The National Referral Centre for Science and Tech- nology}

The National Referral Centre for Science and Technology, established last August in the Library of Congress with the support of the National Science Foundation, has initiated its referral service, but is still in the early stages of developing the comprehensive inventory required. The four major responsibilities of the Centre are: to identify all significant information resources in the fields of science and technology; to acquire, catalogue, and correlate substantive and procedural data defining the 